\title{
Higher education gone global \\ Introduction to the special issue
}

\author{
GRITT B. NIELSEN
}

\begin{abstract}
In order to prosper as a so-called knowledge society in a global economy, countries worldwide are increasingly emphasising the need to internationalise their higher education institutions and attract the best and brightest students and staff from abroad. This article explores the shifting rationales for internationalisation and how today, based on novel forms of comparability and exchange, a new and highly stratified arena for higher education is developing. By focusing on the conferences and fairs where actors negotiate and position higher education on various scales, not least a global one, the article introduces the core themes of this special issue and presents one possible context for the following articles.

KEYWORDS

globalisation, global knowledge economy, higher education reform, internationalisation, social imaginary
\end{abstract}

In recent decades a common political credo seems to have emerged about the 'global' situation and the role of higher education within it. The global is configured as a knowledge economy where education, and in particular higher education, is perceived to be the central powerhouse raising the standard of human capital, driving economic growth and playing a key role in securing a country's position in a global competition on knowledge. To meet the challenges of this so-called new era of globalisation, governments and universities worldwide are increasingly emphasising the need to 'internationalise' their education systems and institutions. To prosper as a knowledge society in a global economy, the argument goes, a country's higher education needs to become more internationalised and in particular attract 'the best and the brightest' students and staff from abroad. Across countries and regions, various frameworks, like the European Bologna Process, have 
been implemented to create greater integration and comparability across education systems and make it easier for students (especially within the region) to become more mobile in their educational endeavours. Indeed, in the past 50 years the number of students going to another country to study has grown from approximately 250,000 in 1965 to the current figure of about 3.7 million (de Wit et al. 2013). In this process, internationalisation is combined with new kinds of educational marketisation and commercialisation where education is increasingly recast as the individual's personal investment in his or her own future, rather than as a common or public good.

With the political credo of the knowledge economy, globalisation is seen as a set of compelling and inevitable conditions arriving from some space outside human agency, and internationalisation becomes the strategy that human actors develop to respond to, cope with, or even take advantage of these forces of globalisation (Stromquist 2007). Put another way, globalisation is seen as a cause and internationalisation a response. In this introduction, I suggest instead that globalisation-as-cause is a particular 'social imaginary' (Rizvi 2006) that is being enacted and negotiated by people in particular places. That is, as Massey argues (2005: 83), globalisation is an imaginary which has 'its institutions and its professionals. It is normative; and it has effects'. As the political credo of globalisation-as-cause in the knowledge economy has gained impetus, it seems timely to focus attention on how knowledge about internationalisation and the role of higher education in a so-called globalised world is constantly produced, negotiated and distributed in particular collective, but also highly stratified and uneven, spaces. This is exactly what this special issue aims to do.

This special issue focuses on how efforts to increase internationalisation of higher education go hand in hand with educational marketisation; with new kinds of stratification between countries, institutions and citizens; and with new visions of what competencies and capabilities the ideal student and citizen should possess. Together, the four studies and this introductory article show that globalisation is far from an agentless and inevitable force: rather, identifiable people, governing institutions and businesses pursue and interweave personal, professional, national and regional goals and ambitions in sometimes rather obscure and complex ways and, in doing this, they promote and enact particular, and potentially conflicting, imaginaries of globalisation. Two of the articles (Valentin and Thøgersen) revolve around the central topic of student mobility - an essential and highly researched aspect of contemporary internationalisation of higher education - but they shed 
new light on this issue by focusing on particular cases of mobile Nepalese and Chinese students. Valentin, focusing on Nepalese young people, studies internationalisation at the intersection of educational and labour immigration, a greatly underexplored topic in literature on international higher education, and, in analysing Chinese students' expectations and hopes prior to their stay abroad, Thøgersen provides a unique and important supplement to the growing literature on international students' experiences abroad. The other two articles (Christensen and Sarauw) explore the different political attempts of Singapore and Denmark to educate and attract what they respectively perceive to be a skilled and globally competitive work force. They thereby consider hitherto more neglected dimensions of the political processes of internationalisation and the positioning of higher education on a global scale which work to introduce new power relations and divisions between countries, institutions and people. The four articles also show that it is not just senior government figures, financial and business interests who are the actors; young people from poor countries and aspiring contributors to emerging economies are equally actors in the process of globalisation and the international trade and interaction in higher education.

Geographically the articles cover aspects of internationalised higher education in relation to Singapore, China, Nepal and Denmark. They focus on universities as well as other kinds of higher education institutions like vocational colleges and teacher training institutions. These institutions are all subject to political demands of internationalisation and increasingly work to attract bright students and staff across national and regional borders. In this introduction I mainly focus on the university. I start by considering the historically shifting rationales for the internationalisation of universities and use this as a stepping stone to discuss, first, the dichotomous split between globalisation-as-cause and internationalisation-as-response in more depth and, second, how today, based on new forms of comparability and exchange, a new international or global arena for higher education is developing. In order to do this, I look to the conferences and fairs where actors can be seen in the process of negotiating and positioning higher education on various scales, not least a global one. These explorations provide one possible context for the articles in this special issue. I end by pointing to some central cross-cutting themes and to some of the fundamental challenges facing higher education institutions, their staff and students, as they are encouraged or pressured into engaging in particular initiatives under the equivocal rubric of 'internationalisation'. 


\section{Conflicting rationales for internationalisation}

In various articles, Jane Knight and Hans de Wit (de Wit 1999, 2002; Knight and de Wit 1999; Knight 2006b, 2008) have identified four different but somewhat overlapping rationales for internationalisation: the social/cultural, the political, the academic and the economic. The social/cultural rationale highlights internationalisation as a means for creating national cultural identity, for generating intercultural understanding and for social and community development. The political rationale connects internationalisation to questions of foreign policy, national security, peace and mutual understanding, and national and regional identity. The academic rationale emphasises that internationalisation is beneficial because it extends the academic horizon; it enhances quality and academic standards, and contributes to institution building and to institutions' profile and status. Lastly, the economic rationale focuses on the economic benefits and pitfalls of international relations in education in terms of, for example, profit-making and students' employability.

One could argue that universities, right from their medieval European origin, have been in certain ways international in their scope and nature. With Latin as the lingua franca, scholars and students moved across borders to seek the universal truth about the world. Furthermore, with European discovery of the Americas, European-style universities were established in Lima and Mexico City as early as in the mid-sixteenth century (Scott 2000). Knight and de Wit (de Wit 1999, 2002; Knight and de Wit 1999; Knight 2006b, 2008) show that while the rationales for international engagement in the medieval university could be said to be mainly academic and social/cultural, in that the scholars were motivated by a search for knowledge and an understanding of other cultures, in the nineteenth and twentieth centuries the connection between universities and the development of the nation-state became increasingly important. Universities played a significant role - first on the European continent, later in post-colonial countries of the global South - in developing national culture and identity as well as educating a qualified work force. After the Second World War a political rationale became dominant, putting emphasis on internationalisation as a means to promote national security and identity as well as peace and mutual understanding.

Since the 1990s 'internationalisation' has increasingly become a key priority and a political buzzword in most countries. Today, the notion of internationalisation is no longer just about mobile students and staff (although this still plays a central role); it includes a wide range of activities like bring- 
ing so-called global/international elements into the curriculum, the provision of courses in English, the establishment of branch campuses in other countries, franchising of programmes and the export of education systems and programmes. Some scholars argue that these developments could be seen as a re-internationalisation of universities to the extent that the strong ties to the nation-state, which were characteristic of the nineteenth and twentieth centuries, are now once again loosened (see Teichler 2004). This (re-)internationalisation, however, seems to take place according to different rationales than, for example, a common quest for universal knowledge or the development of cross-cultural understanding. Indeed it may come as no surprise that Knight and de Wit argue that today 'internationalisation' initiatives are increasingly driven by an economic rationale in terms of, among other things, education for a global/national labour force, competitiveness within research and development, and a focus on marketing and exporting higher education internationally. In short, with the contemporary emphasis on an economic rationale, internationalisation is more and more seen as a necessity and crucial competitive factor for nations, institutions and individuals alike if they want to 'survive' in what is perceived as a new and challenging era of globalisation.

\section{Internationalisation as response to globalisation: a dominant social imaginary}

This understanding of 'globalisation' as an inevitable force, coming from some kind of outside or exterior, and of internationalisation as a necessary and logical human response to this downward pressing force is not only prominent amongst many politicians, policy-makers and university leaders. Scholars at the centre of studies of globalisation and internationalisation of higher education, like Knight and de Wit mentioned above, also promote this notion (see Kälvermark and van der Wende 1997; de Wit 1999; Altbach 2004; Knight 2006b, 2008; Altbach and Knight 2007; van der Wende 2007). Knight and de Wit see internationalisation as a response to globalisation, and one which includes both international and local elements in a 'process of integrating an international/intercultural dimension into the teaching, research and service functions of the institution' (de Wit 1999: 2). Likewise, Altbach and Knight (2007: 290) emphasise that 'Internationalization is often confused with globalization. We define globalization as the economic, political and societal forces pushing $21^{\text {st }}$ century higher education toward greater 
international involvement'. Globalisation, here, is mobilised as explanation. It is seen as largely unalterable (Altbach and Knight 2007: 291) and inevitable (Altbach 2004), whereas agency and choice is located within the processes of internationalisation.

The dichotomous framework of globalisation-as-cause and internationalisation-as-response is persuasive and seductive. It seems quite commonsense and as an analytical framework it is easily applicable to various fields of study. However, the reification of globalisation as an objective and systemic phenomenon has a series of unfortunate consequences. Such a notion reduces globalisation to a simple explanatory backdrop - an abstract deterministic force positioned outside any domain of social contestation and negotiation (see also Cantwell and Maldonado-Maldonado 2009). Globalisation simply just $i$. And as an objective reality globalisation is believed to have effects and consequences in the 'local' but cannot itself be influenced or contested; the 'global' is powerful, whereas the 'local' is positioned as reactive and potentially vulnerable (Robertson 2006). Furthermore, the dominant neo-liberal image of a global knowledge economy projects globalisation (understood as global market forces) as a level playing field of exchange. Questions of unequal power relations, and of how particular actors restrict others and work to produce (notions of) globalisation to their own benefit, are thereby too easily averted.

In contrast, approaches to globalisation within anthropology (Tsing 2000, 2005) and feminist geography (Massey 1994, 2005) challenge this understanding of globalisation as the inevitable force heralding a new era. They understand 'globalisation' and 'the global' as the unstable outcome of multiple local contestations (in our case, about internationalised education) rather than as the structural context for particular actions and practices. Instead of seeing the global, national and local as separated, static or nested positions, both Tsing and Massey argue that the local and the global should be understood as co-constitutive and relational, and that, in our analyses of global encounters, we cannot in advance assume the importance, interconnection or meaning of particular spatial scales (e.g. local, national, regional, global). As we shall see later, different actors variously position higher education on a so-called local (often meaning 'institutional'), national, regional and global scale - reflecting their particular position and power within the larger field of international higher education actors.

An important analytical task, as Tsing (2000) points out, could therefore be to explore such processes of scale-making and how they are intercon- 
nected with the evocation of particular worlds. That is, by interrogating the categories of the global/local/national as performative socio-cultural practices, rather than as a mere response to abstract forces of globalisation, the growing efforts to internationalise education can be analysed as particular kinds of world-making practices where certain versions of the global, as well as of, for example, the national or regional are enacted. Drawing on Arjun Appadurai, Fazal Rizvi (2006) evokes the concept of 'social imaginaries' as a way to capture how such worlds are constantly made and remade in collective spaces. A social imaginary is not a question of pure or individual imagination, rather it is a shared cosmology or understanding of the world one lives in - a kind of collective, social fact (Rizvi 2006: 194). In line with Appadurai's argument that the increased flows of people, capital and images have made imagination 'a critical part of collective, social, everyday life and ... a form of labor' (Appadurai in Rizvi 2006: 193), Rizvi states that social imaginary involves 'processes through which people engage with ordinary life, consider options and make decisions ... in new forms of collaborations that are no longer confined to local communities but span across national boundaries' (Rizvi 2006: 193). Central questions then become how current efforts to internationalise higher education enact and draw on particular imaginaries about the global, the national, the local and so on; how such imaginaries are negotiated, distributed and potentially reshaped; and how, in these negotiations, various higher education systems, institutions and individuals are positioned on particular scales. In other words, as an alternative to seeing 'globalisation' as an explanatory and objective backdrop for our analyses, studies of the internationalisation of higher education would be better served by engaging the concept of globalisation in one of the following ways: first, as Sarauw and Christensen do in their articles, the focus can be on how globalisation is evoked as a political and empirical concept to promote particular practices, initiatives and policies; second (as suggested above) globalisation can be used as an analytical term in the very basic sense of activities that position, negotiate or distribute something (in our case higher education) on a so-called global scale. I provide an example of this latter approach in a later section where I discuss the international education conferences as strategic sites for positioning higher education at a global scale. But first, let us take a closer look at some of the processes within the field of higher education that work to establish, promote and distribute a particular social imaginary about the role of education in a socalled globalised world. 


\section{Global convergence in education policy?}

In his article on 'Imagination and the globalisation of educational policy research', Fazal Rizvi (2006) - in line with Tsing and Massey's performative enquiries - emphasises that 'the circulation of educational ideas and ideologies is not merely a function of globalisation but involves actual historical processes, human agents, organisations, and governments within a framework of particular configurations of power and hegemonic relations' (Rizvi 2006: 202). He discusses how a growing global convergence of educational policy ideas around neo-liberal precepts has been promoted by four interconnected phenomena (see also Rizvi 2004).

The first phenomenon is the emergence of a new kind of inter- and transnational policy space, shaped mainly by intergovernmental organisations such as the UNESCO, the European Union and the OECD, in which particular ideas and ideologies about the global situation and the role of higher education are distributed and circulated. Henry et al.'s (2001) analysis of the OECD provides a good example of this: they argue that the OECD has played a major role in promoting the idea of internationalisation as a means for universities to 'become more responsive to the OECD's interpretation of economic globalization' (Henry et al. 2001: 145). In other words, they argue, the OECD has promoted globalisation as a neo-liberal world-order of competitive market forces - an understanding which has gained further impetus with the inclusion of higher education as a trade service to be liberalised in the General Agreement on Trade and Services (GATS) (see e.g. Knight 2006a; Verger 2008). Second, Rizvi argues that a neo-liberal imaginary is becoming dominant through international conventions like the 1990 Washington consensus, which put forward a series of economic policy prescriptions for reforming developing countries by Washington-based institutions including the International Monetary Fund (IMF) and the World Bank. Consequently, and third, coercive strategies, such as conditions attached to World Bank loans to developing countries, have forced these countries to open up their markets to foreign private education providers and reform their education systems according to particular ideas about economic growth and competitiveness. Fourth and last, the establishment of new forms of cooperation between nations, as in the European Bologna Process, which aims to establish a European Higher Education Area and increase mobility and transparency within the region, Rizvi argues, promotes neo-liberal ideologies of marketisation, privatisation and competition even though introduced under a framework of collaboration. 
In addition to the four phenomena Rizvi describes, contemporary internationalisation of higher education is also formed and driven by a growing number of professionals and officials working within the field of internationalisation of higher education (from student recruitment agencies and language test providers to expanding international offices and new deans and vice presidents for international affairs, see Amit 2010). Indeed, the fast growing size and number of international education conferences for professionals, politicians, policy makers, university leaders, administrators, academics as well as private firms and consultancy companies testify to the current and still rising enthusiasm surrounding the 'internationalisation' of higher education. And, regardless of how the conference discussions feed policy debates in particular countries, their workings as a so-called global platform for an expanding number of countries, institutions and individuals to negotiate internationalisation is worth exploring in itself.

Even though the economic rationale for internationalisation is undoubtedly important, de Wit (1999) and Knight (2004, 2008, 2011) show other rationales in play. In this regard Rizvi's description of a transition in education policies towards a neoliberal imaginary may seem a bit too uniform and generalised (it is, for example, disputed to what extent the Bologna Process promotes neoliberal ideologies; see e.g. Wächter 2004). Rationales of internationalisation are not just distributed but also contested and negotiated in particular collective spaces - one such space is established with international education conferences. In 2011, I did field work at the Going Global conference in Hong Kong and the European Association for International Education (EAIE) conference in Copenhagen. In the following I draw on this ethnographic material.

\section{Partnerships and reputation: becoming visible on a global scale}

Consider the British Council's so-called 'Going Global' conferences. Launched in 2004, and with a name that clearly signals a move of higher education towards a 'global' scale, the conference has grown from a bi-annual event in the U.K. to an annual event 'travelling the globe', as the British Council explains on their website. Like the annual and somewhat bigger conferences of the European Association for International Education (EAIE) and the American NAFSA (the American Association of International Educators), the Going Global conference works as a strategic site for producing and negotiating imaginaries of the global situation and the role of higher education within it. 
The conference is promoted as an 'open forum for policy makers and practitioners from around the world to discuss issues facing the international education community' and attracts more than 1,000 registered delegates from the higher education sector and other industries working with international education in different ways. Like most other conferences, these international education conferences include features like paper presentations and panel discussions, workshops and poster sessions. But they also (and especially the EAIE and NAFSA) work as market places in a much more direct manner: they organise a fair for education institutions, national agencies, consultants and firms who seek to promote their institutions/countries and advertise or sell particular products related to internationalised higher education (for example, student recruitment packages, English language tests, analyses of trends on the student market).

In addition to providing knowledge about recent trends within the internationalisation of higher education, these conferences promise to be central sites for networking, strategic exchange and reputational positioning. For example, a 2012 NAFSA booklet encouraged people to attend their conference in order to 'connect with more than 8,000 of your colleagues; develop strategic partnerships for your institution; raise your institution's profile; discover the latest research, best practices and trends in the field'. Likewise, in 2011 when I talked to various academics and leaders of higher education institutions at the Going Global in Hong Kong and the EAIE in Copenhagen their main ambition with the conference was to obtain knowledge of the latest developments in international education (some of the most visited sessions revolved around how to use social media like Facebook and Twitter to attract students) and forge strategic partnerships with other institutions. As one Head of Department at a Japanese university explained to me at the Going Global conference, this field of strategic and global networking becomes quite stratified:

It's all about networking and getting inspiration for how to promote yourself and your own institution. There are different leagues, and most people can only dream about partnering with universities like Cambridge or Harvard. There are like different circles of people and institutions - you have to find the ones that match yourself.

Similarly, another participant, in charge of an international programme at a Finnish university, described these conferences as having a kind of 'black 
market' where you have to know how to position yourself strategically, meet the right people and sell yourself at the 'highest price', that is obtain partnerships with well-known and high ranked universities. In this manner, the international education conferences not only work as trade fairs in goods and knowledge but also, and perhaps most importantly, in reputation and positioning.

Michael Power et al. (2009) have shown that, in response to the growing focus and use of evaluations and ranking systems, organisations and institutions are increasingly concerned with securing their reputation. 'Reputational risk', Power et al. argue, has become a pervasive logic of organising. Many universities believe that a greater number of international partnerships and network memberships make them more prestigious and attractive to other institutions as well as to students. However, as Jane Knight (2011) has argued, most of these partnerships are not really active. The number of partners is merely posted on websites to convey a sense of attractiveness and importance but often they remain sheer paper-based agreements - a show-off to position oneself on the global arena of higher education.

Such partnership practices resonate well with Simon Marginson's argument that in 'the neo-liberal imagination, global higher education is conceived as a network of stand-alone universities scattered across every country in the world, trafficking with each other and competing with each other (and hence similar to each other)' (Marginson 2002: 413, cited in Amit 2010: 8). And indeed, at the Going Global 2011 in Hong Kong, the use of a so-called Spotme device for networking seems symptomatic of this kind of subject formation and the type of exchange the actors of internationalisation (are expected to) engage in. Spotme is a personal, wireless and handheld conference device that enables participants to obtain knowledge about each other, and thus interact, in new ways. When circulating in a room, you can activate a radar to scan the neighbourhood and identify people within a 30 metres radius. You can exchange business cards electronically, send instant messages and, through a so-called 'spot' function, be alerted if you are close to a person you want to meet. The Spotme device fits perfectly with the imaginary, described by Marginson, of autonomous entrepreneurs entering into competition and strategic collaboration on one common and global playing field: you, yourself, are at the centre, trying to get others to 'spot you', attracting them to your network and thereby making yourself visible and important making yourself a strong actor on the global market of education. ${ }^{1}$ 


\section{Internationalisation on a level playing field?}

What the Spotme device does not make visible to the larger public is that the networking at these conferences is highly stratified and not taking place on a completely level playing field. The stratification indeed becomes much more obvious through another and more classic networking device, namely the notice board. At the 2011 European Association for International Education (EAIE) conference, which attracted more than 4,200 participants, a series of white notice boards had been put up to facilitate communication between participants. One row of notice boards was organised according to world regions and had titles like 'Europe', 'Asia', 'Middle East', 'Oceania', 'Africa' etc. On small prefabricated blue notes, with the headline 'I am searching for a partner', participants could detail which country/region, which academic area and what kind of collaboration (e.g. Erasmus student exchange or faculty exchange) they were interested in. Given that it was an EAIE conference it is perhaps not a great surprise that the 'European' notice board was full of these small blue notes. It nevertheless seems striking that whereas 'Asia' and 'the Middle East' had a good handful of posters, Oceania had a single one, and Africa had none. These notice boards put into perspective the stratified and 'black market' of internationalisation mentioned above - as does the comment of the Secretary-General and Chief Executive of the Association of African Universities at the Going Global conference's opening plenary: 'African universities struggle to become players in global education'. Indeed, many countries and institutions never even make it to one of these conferences.

The International Association of Universities' $3^{\text {rd }}$ Global Survey Report (IAU 2010) shows how universities in Africa, Latin America and the Middle East do not assign the same level of importance to internationalisation as universities in, for example, Asia and Europe. There are far fewer collaborations and partnerships with universities in these former regions that are not among the priority areas for establishing partnerships for anybody but themselves. The report also shows how the rationales for internationalisation have not only shifted over time as we saw above but also vary greatly from region to region (Knight 2008; IAU 2010). Whereas other regions ranked 'Improving student preparedness for a globalised world' as the most important rationale for internationalisation, Africa, in contrast, identified 'strengthen[ing] research and knowledge capacity production' as the top rationale for internationalisation and the Middle East ranked the two as equally important. Furthermore, and to put the earlier discussion about reputational risk in per- 
spective, the survey showed that mainly European universities highlighted 'reputation' as one of the main goals of internationalisation. In short, the aim of attracting the best and the brightest students from all over the world and preparing them to become leaders and effective players in a perceived global economy seems to be reserved to the global North and certain emerging economies.

The different rationales for and understandings of 'internationalisation' also seem to be related to the way different spatial scales are combined and evoked as relevant by different countries, institutions and individuals. The Secretary-General of the Association of African Universities, mentioned above, argued that whereas African higher education should be internationally oriented it should also be locally relevant and focused on solving the problems and challenges faced by African countries. In this perspective students are mainly to perceive of themselves as citizens of a particular African country or of the African continent in general and focus their studies on problem-solving there. However, as we shall see in the following case of Hong Kong which was hosting the 2011 Going Global conference, different rationales for internationalisation often intersect and potentially conflict, in that education is variously promoted to develop students as national, regional and global citizens.

\section{Conflicting forms of citizenship?}

In the Going Global conference programme the secretary for education in Hong Kong explained how, in order to 'rise to the challenges of the increasingly globalised and competitive knowledge economy, Hong Kong attaches great importance to education and aspires to become a regional education hub, nurturing and drawing talents for Hong Kong, the region and the world' (British Council 2011). This quotation reflects several interesting features. First, Hong Kong's aspiration to become an education 'hub' is worth paying attention to. The notion of a hub has become increasingly popular and is often used to promote or brand a city or region as an attractive and innovative education centre on the global educational landscape (see also Christensen, this issue, and Robertson 2009). At the 2011 Going Global conference, for example, Sri Lanka attempted to promote itself as a new education hub in South Asia and accordingly argued that it would be an excellent choice of location for the 2013 Going Global conference. Tellingly, however, it was 
later decided that the conference was to be held in Dubai - a city and emirate that in recent years increasingly has gained status as an education hub through attracting a great number of international branch campuses to their so-called Dubai Knowledge Village and Dubai International Academic City. Second, with the emphasis on 'nurturing and drawing talents for Hong Kong, the region and the world', the secretary for education presented the scales of the city, the region and the globe side by side. But no explanation was offered as to how they could or should relate to each other and how a 'talent pool' developed in or attracted to Hong Kong would benefit the rest of the world.

A closer look at the major reform of the Hong Kong education system, launched in 2009, shows that the introduction of a so-called New Academic Structure (NAS) is used in different ways to position Hong Kong's education as relevant on all of these scales. For example, the University of Hong Kong, one of Asia's highest ranking universities, puts great emphasis on educating students to become so-called global citizens who can act as leaders and advocates for the improvement of the human condition. Rather than a purely economic rationale, a different kind of ethico-social rationale for internationalisation is promoted here. The University of Hong Kong, in line with the general NAS reforms, now puts emphasis on some of the same pedagogical principles as many Western countries, namely whole-person development, lifelong learning and experiential and service learning. The university has introduced a common core curriculum, which is to explore 'common human experiences' and strongly encourage students to undertake international study or work. Here, the students are apparently not just to become citizen-workers helping to drive up the local economy. Seemingly, university education is (also) to provide the student with a new kind of moral and civic education to foster international engagement and global awareness (see also Fearn 2010). In contrast, a closer look at the Hong Kong Education Bureau's explanations of the NAS reforms shows they convey a strong focus on Hong Kong's competitiveness:

To maintain Hong Kong's competitiveness in international arena, Hong Kong citizens need to enhance their adaptability, creativity, independent thinking and life-long learning capabilities. The New Academic Structure (NAS) implemented since September 2009 principally aims to prepare students for such future challenges (New Academic Structure Web Bulletin http://334.edb.hkedcity.net/EN/intro.php). 
Similarly, in an advertisement for Hong Kong on Canada's Go Study website it is stated that 'The NAS facilitates the development of the human resources necessary for sustaining the position of Hong Kong as an international city, amidst worldwide changes brought by globalization, economic restructuring, and rapid development in Mainland China..2 On the one hand, emphasis is put on educating Hong Kong citizens in a manner which secures Hong Kong's and its citizens' position in the globalised world. On the other hand, institutions which are have strong international reputations like the University of Hong Kong are promoting new educational visions for a particular, and more ethically grounded, global citizenship. (Alternatively, cynics will perhaps argue that this is just a strategic branding choice to attract students and as such it only reproduces the competitive logic.)

In any case, Hong Kong's reforms show that a central challenge of current efforts to internationalise higher education revolves around two features, namely the kind of subjectivity the student should develop through education (often described in terms of entrepreneurial, flexible, etcetera) and the scale of citizenship, that is if students as citizens should have particular rights and obligations as well as a certain sense of belonging for example to the nation, the region and/or the globe. With the growing emphasis on internationalisation as a necessity for students as well as for institutions and countries to prosper, potential tensions exist between, first, encouraging students to think of education as a private investment in their own future and life conditions; second, educating them to see themselves as primarily 'national' citizens - or in the case of Hong Kong, citizens of a 'hub' - who must align themselves with the interests of capital and help improve a nation's or a city's position in the competitive knowledge economy and, third, educating citizens with a broader outlook, including a global awareness and a democratic concern for the human condition.

In various ways, the articles in this special issue show how different actors - individuals, institutions and countries - with different resources, opportunities and restrictions tend to interweave and combine these potentially conflicting features in very different ways. Furthermore, they show how seemingly similar ideals about the educated person (identified in terms of flexibility, lifelong learning, employability and entrepreneurship) not only come to mean different things in different contexts, but also often are thought of as competencies that are more achievable for some persons than for others. Indeed, across national or regional borders as well as within par- 
ticular countries, populations are differentiated in terms of who has or does not have these competencies, who is likely or unlikely to be able to develop them and, accordingly, who will become mobile and in what ways.

\section{Directions and main themes: new forms of comparability}

In this introduction I have pointed to several central issues and challenges related to higher education going global. I shall highlight three that run through the following four articles of this special issue. First, contemporary efforts to internationalise higher education systems and institutions to a great extent revolve around notions of competitiveness and hierarchical positioning: a so-called global playing field is conjured up where some countries, institutions and individuals become more attractive than others. For countries and institutions this stratification means that some can engage a stronger network and attract better and brighter students and staff; for individuals it means that some become more geographically and socially mobile than others. Accordingly, and second, particular people/citizens are positioned at different spatial scales (e.g. hub, nation, region, globe) with different rights, obligations and opportunities attached. The ideally educated person/citizen, for example, may be offered the opportunity to position themselves at several of these scales; whereas more 'undesirable' citizens do not enjoy a similar flexibility. Third, new ideals have emerged about what capabilities or competencies this desired and educated individual/citizen needs to possess. A certain convergence seems to exist in that most countries emphasise that students should develop the competencies to be flexible, employable, risktaking, have a global outlook and embrace lifelong learning. Yet such ideals - as Christensen's and Sarauw's articles show - are reworked, framed and emphasised in different ways in different political settings. And as we shall see in Thøgersen's and Valentin's articles, individual students also engage these ideals in idiosyncratic ways as they navigate a nation's official education (and migration) policies, the pedagogical and educational ideas of the curriculum, and their own personal or professional aspirations.

Sarauw's study of Denmark's incorporation of the Bologna Process shows that Denmark, by evoking a rather narrow understanding of 'employability', ignored and excluded other aspects, like the development of democratic competencies and of a broad and advanced knowledge base, which are equally emphasised in the general Bologna Process documents as necessary for educating citizens who can meet the challenges of globalisation. Through these 
different responses to the perceived threats and challenges of the global knowledge economy, Sarauw argues, globalisation is in itself enacted in radically different ways: the general documents of the Bologna Process project globalisation as a move towards a more complex and unpredictable world, with the flexible lifelong learner as the ideal citizen. In contrast, the Danish qualification frameworks work to conjure up 'globalisation' as a change towards a smaller and more predictable world, which calls for efficient alignment of the curriculum to specific professional needs.

Christensen's study of Singapore's Global Schoolhouse project provides an extreme example of a country reorganising its higher education to enter into strategic alliances with prestigious foreign institutions and attract the most entrepreneurial, creative and risk-embracing academics and students from around the world, to the neglect of its own population. The result is a new kind of differentiated entrepreneurial citizenship where local Singaporeans, who are perceived as risk-averse and fundamentally conservative, do not enjoy the same privileges as the 'foreign talents', which are believed to boost the transformation of Singapore into a 'world-class' knowledge economy. The expansion of high-quality university education in Singapore, Christensen argues, thereby serves as a vehicle of this 'foreign talent' policy, rather than as an accommodation of the needs of local students for higher education.

Valentin explores the relation between immigration policy and the internationalisation of higher education. She provides a striking example of how Nepalese young people, who have come to study and work in Denmark, have to navigate a confusing nexus of immigration, education and employment rules and regulations. In order to explore the fuzzy boundaries of their status as students-workers-migrants and grasp the multiple factors that made these young people leave Nepal, Valentin argues for a conceptual distinction between 'educational migrants' and 'international students'. In particular, this distinction turns the attention to the complex relationship between processes of mobility and global inequality and hierarchisation between institutions, countries and regions across the world.

Thøgersen studies a Chinese-Danish programme and provides unique insights into a group of Chinese students' reflections, expectations and motivations before going to Denmark to study. He shows how students believe and hope that a stay abroad will make them more 'independent individuals' who can play a central role in developing China into a more creative and innovative economy. In this way, the students interweave the official national 
narrative of China's transition to a more creative and innovative economy with their personal and professional goals. This Chinese-Danish programme brings into conjunction two different concepts and processes of education and Thøgersen shows how the concept of 'individual' is important in both pedagogical traditions but with different histories of meaning.

The four articles and this introduction demonstrate that at the heart of contemporary efforts to internationalise higher education is a new regime of comparability: in positioning higher education on a so-called global playing field - through the instigation of rankings, the formation of university consortia and alliances, cross-national evaluations, tests and convergence in curriculum and educational structures - countries, institutions and individuals are rendered increasingly comparable. Our articles show how different collective and individual actors are encouraged to perceive of themselves through strategic comparison and separation between 'self' and 'other', 'inside' and 'outside', 'local' and 'foreign/global', 'traditional' and 'modern', 'East' and 'West'. This kind of comparison and positioning points to the continuous stratification and hierarchisation at work in contemporary processes of internationalisation.

The uneven playing field of international education and the growing role played by commercial interest in shaping it has recently led to attempts to put more emphasis on the pitfalls of current internationalisation processes (including the potential threat to quality of marketisation and trade in higher education), and promote a more ethically grounded notion of internationalisation (see e.g. Mathisen 2008). In order to affirm academic, rather than commercial, values in internationalisation, the International Association of Universities (IAU) has launched an International Ad-hoc Expert Group on Rethinking Internationalization. Likewise the European Association for International Education (EAIE), at their 2012 conference adopted a new student mobility charter to secure the international students' rights and welfare, for example by ensuring that students are integrated into the academic institution and the wider community, and are assisted in protecting their rights. Furthermore, the charter urges institutions and countries to consider the effect - both positive and negative - that the global movement of students has on both the sending and the hosting countries.

By exploring how particular countries, institutions and individuals engage with and develop contemporary internationalisation of higher education - and how new hierarchical divisions between countries, institutions and people are established - it is our hope that this special issue will con- 
tribute to the recent attempts to reconsider the field of internationalisation on more social and ethical grounds.

Gritt B. Nielsen is assistant professor, Ph.D., in educational anthropology at Aarhus University. Her main research interests are in internationalisation and marketisation of higher education; anthropology of policy, state and governance; political participation and new forms of student subjectivity. Email: gbn@dpu.dk

\section{Notes}

1. Interestingly, this notion of an actor fits with Latour's notion of an 'actor' in the hyphenated expression of the actor-network. An actor, Latour says, is 'not the source of an action but the moving target of a vast array of entities swarming toward it' (Latour 2005: 46). That is, the stronger a network, the stronger an actor.

2. http://gostudy.ca/study-overseas/hong-kong/preparing-for-the-21st-century-hong-kon gs-educational-reform-and-attraction-for-foreign-youngsters.html

\section{References}

Altbach, P. (2004) 'Globalisation and the university: myths and realities in an unequal world', Tertiary Education and Management 10, no. 1: 3-25.

Altbach, P. and Knight, J. (2007) 'The internationalization of higher education: motivations and realities', Journal of Studies in International Education 11, nos. 3 and 4: 290-305.

Amit, V. (2010) 'Student mobility and internationalisation: rationales, rhetoric and 'institutional isomorphism', Anthropology in Action 17, no. 1: 6-18.

British Council (2011) Going Global conference programme, http://www.britishcouncil .org/goingglobal-gg5-full-programme-pdf

Cantwell, B. and Maldonado-Maldonado, A. (2009) 'Four stories: confronting contemporary ideas about globalisation and internationalisation in higher education', Globalisation, Societies and Education 7, no. 3: 289-306.

de Wit, H. (1999) 'Changing rationales for the internationalization of higher education', International Higher Education 15, spring: 2-3.

de Wit, H. (2002) Internationalization of Higher Education in the United States of America and Europe: A Historical, Comparative and Conceptual Analysis, Westport, CT: Greenwood Press. 
de Wit, H., Ferencz, I. and Rumbley, L. E. (2013) 'International student mobility’, Perspectives: Policy and Practice in Higher Education 17, no. 1: 17-23.

Fearn, H. (2010) 'Extreme makeover', Times Higher Education, 4 February.

Henry, M., Lingard, B., Rizvi, F. and Taylor, S. (2001) The OECD, Globalisation and Education Policy, Oxford: IAU Press, Pergamon.

IAU (2010) Internationalization of Higher Education: Global Trends Regional Perspectives. Third IAU Global Survey Report, Paris: IAU.

Kälvermark, T. and van der Wende, M. C. (eds) (1997) National Policies for Internationalisation of Higher Education in Europe, Stockholm: National Agency for Higher Education.

Knight, J. (2004) 'New rationales driving internationalization', International Higher Education 34, winter: 3-5.

Knight, J. (2006a) Higher Education Crossing Borders. A Guide to the Implications of the General Agreement on Trade in Services (GATS) for Cross-border Education. A Report Prepared for the Commonwealth of Learning and UNESCO, France: COL/UNESCO.

Knight, J. (2006b) 'Internationalization: concepts, complexities and challenges', in J. J. F. Forest and P. G. Altbach (eds) International Handbook of Higher Education, Dordrecht: Springer, 207-227.

Knight, J. (2008) 'The internationalization of higher education: complexities and realities', in D. Teferra and J. Knight (eds) Higher Education in Africa: The International Dimension, Accra/Boston: AAU/CIHE: 1-43.

Knight, J. (2011) 'Five myths about internationalization', International Higher Education 62, winter: 14-15.

Knight, J. and de Wit, H. (eds) (1999) Quality and Internationalization in Higher Education, Paris: Organization for Economic Cooperation and Development.

Latour, B. (2005) Reassembling the Social. An Introduction to Actor-Network-Theory, Oxford: Oxford University Press.

Marginson, S. (2002) 'Nation-building universities in a global environment: the case of Australia', Higher Education 43, no. 3: 409-428.

Massey, D. (1994) Space, Place, and Gender, Minneapolis: University of Minnesota Press.

Massey, D. (2005) For Space, London: Sage.

Mathisen, G. (2008) 'Shaping the global market of higher education through quality promotion', in D. Epstein, R. Boden, R. Deem, F. Rizvi and S. Wright (eds) World Yearbook of Education 2008. Geographies of Knolwedge, Geometries of Power: Framing the Future of Higher Education, New York and London: Routledge, 266-279.

Power, M., Scheytt, T., Soin, K. and Sahlin, K. (2009) 'Reputational risk as a logic of organizing in late modernity’, Organization Studies 30, nos. 2 and 3: 301-324.

Rizvi, F. (2004) 'Theorising the global convergence of restructuring policies in education', in S. Lindblad and T. Popkewitz (eds) Educational Restructuring: International Perspectives on Travelling Policies, Greenwich, CT: Information Age Publishing, 21-42. 
Rizvi, F. (2006) 'Imagination and the globalisation of educational policy research', Globalisation, Societies and Education 4, no. 2: 193-205.

Robertson, S. L. (2006) 'Absences and imaginings: the production of knowledge on globalisation and education', Globalisation, Societies and Education 4, no. 2: 303-318.

Robertson, S. L. (2009) 'Metaphoric imaginings: re/visions on the idea of a university', in R. Barnett, J.-C. Guédon, J. Masschelein, M. Simons, S. L. Robertson and N. Standaert (eds) Rethinking the University After Bologna: New Concepts and Practices beyond Tradition and the Market, Antwerp: UCSIA, 20-30.

Scott, P. (2000) 'Globalisation and higher education: challenges for the 21st century', Journal of Studies in International Education 4, no. 3: 3-10.

Stromquist, N. P. (2007) 'Internationalization as a response to globalization: radical shifts in university environments', Higher Education 53, no. 1: 81-105.

Teichler, U. (2004) 'The changing debate on internationalisation of higher education', Higher Education 48, no. 1: 5-26.

Tsing, A. (2000) 'The global situation', Cultural Anthropology 15, no. 3: 327-360.

Tsing, A. (2005) Friction: An Ethnography of Global Connection, Princeton and Oxford: Princeton University Press.

van der Wende, M. C. (2007) 'Internationalization of higher education in the OECD countries: challenges and opportunities for the coming decade', Journal of Studies in International Education 11, nos. 3 and 4: 274-289.

Verger, A. (2008) 'The constitution of a new global regime. Higher education in the GATS/WTO framework', in D. Epstein, R. Boden, R. Deem, F. Rizvi and S. Wright (eds) World Yearbook of Education 2008. Geographies of Knolwedge, Geometries of Power: Framing the Future of Higher Education, New York and London: Routledge, 111-127.

Wächter, B. (2004) 'The Bologna Process: developments and prospects', European Journal of Education 39, no. 3: 265-273. 